\title{
Hubungan Pola Makan Dan Stres Dengan Kejadian Gastritis Pada Mahasiswa Fakultas Ilmu Kesehatan Universitas Ibn Khaldun
}

\section{The Relationship Between Diet And Stress With Incident Of Gastritis In Student At Faculty Of Health Scienc Ibn Khaldun University}

\author{
Kintan Aulia Amanda ${ }^{1}$, Arissanti Isra' Firdausy ${ }^{2}$, Siti Walidaturrahmah Alfaeni ${ }^{3}$, Novita Amalia ${ }^{4}$, Nur Afifah \\ Rahmani $^{5}$, Ade Saputra Nasution 6
}

\begin{abstract}
1,2,3,4,5Program Studi Kesehatan Masyarakat, Fakultas Ilmu Kesehatan, Universitas Ibn Khaldun Bogor Email corespondensi : $\underline{6 \text { adenasution@uika-bogor.ac.id }}$
\end{abstract}

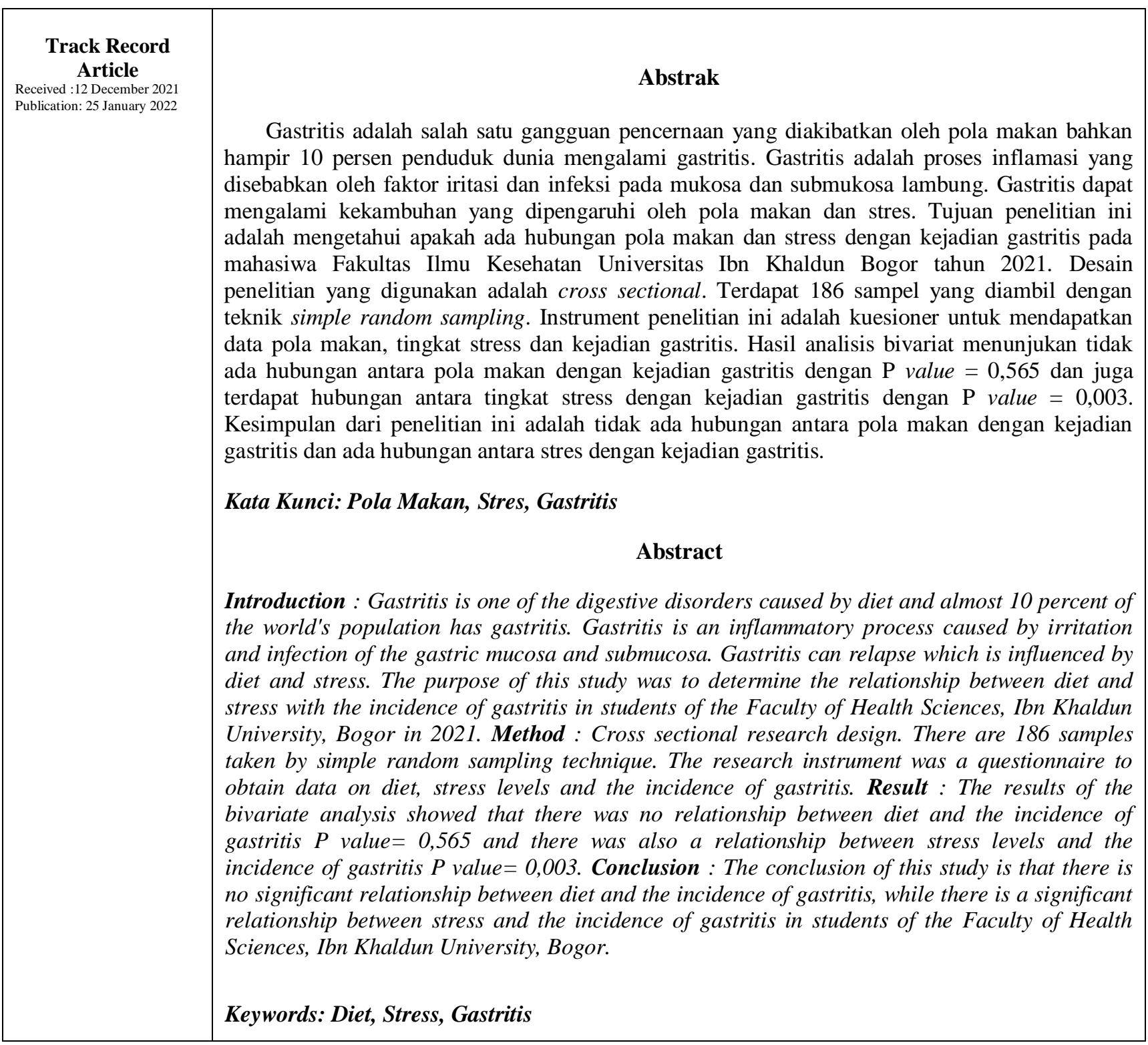




\section{Introduction}

Semakin berkembangnya zaman maka epidemiologi juga mengalami pergeseran yang dulunya lebih menekan ke arah masalah penyakit menular kini menekan ke arah masalah kesehatan yang ruang lingkupnya sangat luas. Hal ini terjadi karena banyaknya perubahan pada masyarakat seperti perubahan pada pola penyakit, pola hidup, tingkat ekonomi masyarakat, peningkatan sosial dan semakin luasnya jangkauan masyarakat. Penyakit tidak menular akibat perubahan gaya hidup masyarakat salah satunya adalah penyakit pada sisitem pencernaan (Diliyana, 2020). Penyakit pada sistem pencernaan merupakan salah satu jenis penyakit tidak menular yang banyak terjadi di masyarakat, yang tentunya akan mempengaruhi aktivitas dan pola hidup, salah satunya penyakit Gastritis. Penyakit gastritis adalah salah satu gangguan pencernaan yang diakibatkan oleh pola makan bahkan hampir 10 persen penduduk dunia mengalami gastritis (Syafi' $i, 2019)$.

Di berbagai negara kasus kejadian gastritis menunjukkan angka yang cukup tinggi. Tinjauan yang dilakukan oleh World Health Organization WHO terhadap penyakit gastritis di beberapa negara dunia ditemukan presentase yaitu, Inggris $22 \%$, Jepang 14,4\%, Kanada 29, 5\%, China 31\% dan Prancis sekitar 29,5\%. Insiden gastritis di dunia sekitar 1.8-2,1 juta dari jumlah penduduk setiap tahun. Kasus terjadinya gastritis di wilayah Asia Tenggara mencapai 583.638 kasus dari jumlah penduduk setiap tahunnya (Merita , 2016)

Prevalensi kejadian gastritis di Indonesia yaitu 274,396 kasus dari 238,452,952 jiwa penduduk. Menurut data dari Departemen Kesehatan RI angka presentase kejadian gastritis di Indonesia adalah 40,8\% (Anshari, 2019). Data dari Kemenkes 2015, angka kejadian gastritis di Jawa Barat mencapai 31,2\% dan daerah dengan penderita penyakit terbanyak adalah Kota Bandung dengan angka mencapai 15,37\% (Wahyuni, 2018). Berdasarkan studi pendahuluan yang dilakukan pada mahasiswa fakultas ilmu kesehatan Universitas Ibn Khaldun Kota Bogor, dari 60 orang mahasiswa diketahui sebanyak 38 orang memiliki riwayat penyakit gastritis (maag). Hal ini membuktikan bahwa angka kejadian gastritis pada mahasiswa fikes UIKA masih cukup tinggi.

Sebanyak 10 mahasiswa dan 20 responden dari 10 mahasiswa di asrama mahasiswa Universitas Airlangga menemukan bahwa hingga 50\% mahasiswa tidak makan sayur dan buah setiap hari. Enam puluh persen siswa yang tinggal di asrama campuran makan hanya satu porsi buah sehari. Konsumsi sayur meningkat sebesar 35\% untuk 1 porsi per hari dan 65\% untuk 2 porsi per hari (Dhaneswara, 2016).

Rata-rata anak dan remaja hanya makan lauk pauk, karena banyak anak yang tidak menyukai sayur dan jarang makan buah (Putri, 2019; Emryssyah, 2021). Anak-anak dan 
remaja kurang suka sayur, hanya beberapa sayur yang jarang mereka makan serta konsumsi buah Sayur dan buah harus divariasikan agar mendapatkan berbagai sumber vitamin atau mineral dan serat. Remaja memiliki pilihan makanan tersendiri dan seorang remaja memiliki kebiaasaan makanan tersendiri (Adinda, 2020). Konsumsi makanan yang tidak baik akan meningkatkan resiko terjadi berbagai penyakit (Susanti, 2020).

Tidak bisa dipungkiri pada zaman yang modern ini pola hidup manusia jauh dari kata sehat karena kebiasaan-kebiasaan yang buruk seperti sering mengkonsumsi junk food, makan tidak tepat pada waktunya, makan tanpa memperhatikan kebersihan lingkungan sekitarnya dan makan tidak dengan memperhatikan nilai gizi dari makanan yang dikonsumsi. Kebiasaan-kebiasaan tersebut menjadi risiko yang besar untuk terkena penyakit Gastritis. Penyakit Gastritis ini bila tidak diatasi dengan cepat maka dapat menimbulkan pendarahan sehingga banyak darah yang keluar dan berkumpul di lambung, selain itu juga dapat menimbulkan tukak lambung ataupun kanker lambung sehingga dapat menyebabkan kematian (Merita et al., 2016).

Pada dasarnya penyebab gastritis dibedakan menjadi dua bagian besar yaitu faktor internal dan faktor eksternal, faktor internal merupakan adanya keadaan memicu terjadinya pengeluaran asam lambung yang berlebihan, dan beberapa zat eksternal yang menyebabkan lambung menjadi infeksi dan iritasi. Faktor risiko gastritis beberapa diantaranya seperti memakai obat aspirin atau antiradang non steroid, memiliki kebiasaan meminum minuman beralkohol/bersoda, memiliki kebiasaan merokok, memiliki kebiasaan makan yang buruk seperti waktu makan yang tidak teratur dan terlalu sering mengkonsumsi makanan yang pedas dan asam, infeksi kuman Helicobacter pylori (Handayani, 2018). Selain itu, pada keadaan stres seperti cemas, takut, beban kerja yang berlebihan atau terburu-buru ketika mengerjakan sesuatu megakibatkan produksi asam lambung akan naik, jika kadar asam lambung meningkat maka dapat mengiritasi mukosa lambung dan jika dibiarkan dapat menjadi penyebab terjadinya gastritis (Ausrianti, 2019).

Penelitian terdahulu dengan judul “ Hubungan Pola Makan Dengan Resiko Gastritis Pada Mahasiswa Yang Menjalani Sistem KBK" menyatakan bahwa ada hubungan antara pola makan dengan resiko gastritis pada mahasiswa dimana pola makan yang tidak teratur dapat mempengaruhi resiko gastritis (Hartati, 2014). Adapun penelitian yang dilakukan oleh Zainurridha (2021) dengan judul "Stres dan Pola Makan Terhadap Kejadian Gastritis Pada Mahasiswa Keperawatan STIKES Bhakti Al-Qodori" menyatakan bahwa terdapat hubungan yang signifikan dengan antara stres dengan kejadian gastritis. 
Menurut Ausrianti (2019) hasil penelitian ini menunjukkan adanya hubungan antara stres dan pola makan dengan kejadian gastritis. Responden yang memiliki resiko stres berpeluang 5,2 kali untuk menderita gastritis. Sementara itu responden yang memiliki pola makan tidak baik mempunyai peluang 4,2 kali untuk menderita gastritis.

Penelitian ini memiliki tujuan untuk mengetahui hubungan pola makan dan stres yang terdiri dari variabel independen yaitu pola makan dan stres dan variabel dependen yaitu kejadian gastritis pada mahasiswa Fakultas Ilmu Kesehatan Universitas Ibn Khaldun Bogor tahun 2021.

\section{Methods}

Desain penelitian yang digunakan pada penelitian ini adalah cross sectional yaitu suatu desain penelitian yang digunakan untuk mempelajari dinamika korelasi antara faktorfaktor risiko dengan dampak yang ditimbulkan, pendeketan ini dilakukan dengan cara pengumpulan data atau observasi sekaligus pada kondisi waktu tertentu atau point time approach (Notoatmodjo, 2014)

Populasi pada penelitian ini merupakan mahasiswa aktif semester 2-6 Fakultas Ilmu Kesehatan Universitas Ibn Khaldun Bogor yang berjumlah 347 orang. Besaran sampel penelitian dihitung menggunakan rumus slovin dengan tingkat kemaknaan 5\%, sehingga diperoleh jumlah sampel sebanyak 186 orang. Teknik pengambilan sampel menggunakan teknik simple random sampling.

Alat pengumpul data yang digunakan pada penelitian ini yaitu berupa kuesioner yang berisi beberapa pertanyaan yang dapat digunakan untuk menggali setiap variabel independen dan dependen. Pengambilan data pada penelitian ini dilakukan pada bulan Juni tahun 2021 di Fakultas Ilmu Kesehatan Universitas Ibn Khaldun Bogor. Hasil pengumpulan data diolah menggunakan aplikasi software pengolah data komputerisasi dengan analisis deskriptif dan bivariat. Analisis bivariat dilakukan dengan menggunakan uji statistik chi square dengan taraf kesalahan 5\% atau dikatakan bermakna jika nilai $\mathrm{P}$ value $<0,05$. 


\section{Result and Discusiion}

Tabel 1 Distribusi Frekuensi Karakteristik Responden berdasarkan Jenis Kelamin Pada Mahasiswa Fakultas Ilmu Kesehatan Universitas Ibn Khaldun Bogor

\begin{tabular}{ccc}
\hline Jenis Kelamin & Frekuensi & Persentase \\
\hline Perempuan & 150 & $80,6 \%$ \\
Laki-laki & 36 & $19,4 \%$ \\
\hline Total & 186 & $100 \%$ \\
\hline
\end{tabular}

Berdasarkan tabel 1 bahwa karakteristik responden berdasarkan jenis kelamin lebih banyak perempuan yaitu sekitar 150 orang $(80,6 \%)$ dibandingkan dengan responden lakilaki yaitu sebanyak 36 orang $(19,4 \%)$.

Tabel 2 Distribusi Frekuensi Responden berdasarkan Tingkat Semester Pada Mahasiswa Fakultas Ilmu Kesehatan Universitas Ibn Khaldun Bogor

\begin{tabular}{ccc}
\hline Semester & Frekuensi & Persentase \\
\hline Semester 2 & 60 & $32,3 \%$ \\
Semester 4 & 78 & $41,9 \%$ \\
Semester 6 & 48 & $25,8 \%$ \\
\hline Total & 186 & $100 \%$ \\
\hline
\end{tabular}

Berdasarkan tabel 2 bahwa karakteristik responden berdasarkan tingkat semester lebih banyak semester 4 yaitu sekitar 78 orang $(41,9 \%)$ dibandingkan semester 2 dan semester 6 dengan jumlah masing-masing yaitu 60 orang $(32,3 \%)$ dan 48 orang $(25,8 \%)$.

Tabel 3 Distribusi Frekuesnsi Gambaran Kejadian Gastritis Pada Mahasiswa Fakultas Ilmu Kesehatan Universitas Ibn Khaldun Bogor

\begin{tabular}{ccc}
\hline Kejadian Gastritis & Frekuensi & Persentase \\
\hline Gastritis & 102 & $54,8 \%$ \\
Tidak Gastritis & 84 & $45,2 \%$ \\
\hline Total & 186 & $100 \%$ \\
\hline
\end{tabular}

Berdasarkan tabel 3 bahawa responden yang mengalami kejadian gastritis lebih banyak yaitu sekitar 102 orang $(54,8 \%)$ dibandingkan dengan responden yang tidak mengalami gastritis sebanyak 84 orang $(45,2 \%)$.

Tabel 4 Gambaran Pola Makan Pada Mahasiswa Fakultas Ilmu Kesehatan Universitas Ibn Khaldun Bogor

\begin{tabular}{ccc}
\hline Pola Makan & Frekuensi & Persentase \\
\hline Buruk & 94 & $50,5 \%$ \\
Baik & 92 & $49,5 \%$ \\
\hline Total & 186 & $100 \%$ \\
\hline
\end{tabular}


Berdasarkan tabel 4 diketahui bahwa responden yang memiliki pola makan buruk lebih banyak yaitu sekitar 94 orang (50,5\%) dibandingkan dengan responden yang memiliki pola makan baik sebanyak 92 orang $(49,5 \%)$.

\section{Tabel 5 Gambaran Tingkat Stres Pada Mahasiswa Fakultas Ilmu Kesehatan Univeristas Ibn Khaldun Bogor}

\begin{tabular}{ccc}
\hline Tingkat Stres & Frekuensi & Persentase \\
\hline Normal & 20 & $10,8 \%$ \\
Ringan & 16 & $8,6 \%$ \\
Sedang & 27 & $14,5 \%$ \\
Berat & 43 & $23,1 \%$ \\
Sangat Berat & 80 & $43,0 \%$ \\
\hline Total & 186 & $100,0 \%$ \\
\hline
\end{tabular}

Berdasarkan tabel 5 diketahui bahwa responden yang memiliki tingkat stres sangat berat lebih banyak yaitu sekitar 80 orang $(43,2 \%)$ dibandingkan dengan responden yang memiliki tingkat stres normal, ringan, sedang dan berat dengan jumlah masing-masing yaitu 20 orang $(10,8 \%), 16$ orang $(8,6 \%), 27$ orang $(14,5 \%)$, dan 43 orang $(23,1 \%)$.

Tabel 6 Hubungan Pola Makan dengan Kejadian Gastritis Pada Mahasiswa Univeristas Ibn Khaldun Bogor

\begin{tabular}{ccccccc}
\hline & \multicolumn{5}{c}{ Kejadian Gastritis } \\
\cline { 2 - 6 } Mala & \multirow{2}{*}{ Buruk } & 54 & Tidak & Total & OR (CI 95\%) & P Value \\
\hline & & $(57,4 \%)$ & $(42,6 \%)$ & $(100 \%)$ & $(0,694-2,207)$ & 0,565 \\
& \multirow{2}{*}{ Baik } & 48 & 44 & 92 & & \\
& $(52,2 \%)$ & $(47,8 \%)$ & $(100 \%)$ & & \\
\hline \multirow{2}{*}{ Total } & 102 & 84 & 186 & & \\
& & $(54,8 \%)$ & $(45,2 \%)$ & $(100 \%)$ & & \\
\hline
\end{tabular}

Berdasarkan tabel 6 menunjukkan bahwa dari dari 94 orang responden yang memiliki pola makan buruk ditemukan 54 orang $(57,4 \%)$ yang mengalami kejadian gastritis. Selanjutnya, dari 92 orang responden yang memiliki pola makan baik ditemukan sebanyak 48 orang $(52,2 \%)$ yang mengalami gastritis. 
Tabel 7 Hubungan Stres dengan Kejadian Gastritis Pada Mahasiswa Univeristas Ibn Khaldun Bogor

\begin{tabular}{cccccc}
\hline & \multicolumn{4}{c}{ Kejadian Gastritis } & \\
\hline Tingkat & Ya & Tidak & Total & P Value \\
Stres & Normal & 5 & 15 & 20 & 0,003 \\
& & $(25,0 \%)$ & $(75,0 \%)$ & $(100,0 \%)$ & \\
& Ringan & 5 & 11 & 16 & \\
& & $(31,3 \%)$ & $(68,8 \%)$ & $(100,0 \%)$ & \\
& Sedang & 15 & 12 & 27 & \\
& & $(55,6 \%)$ & $(44,4 \%)$ & $(100,0 \%)$ & \\
& Berat & 31 & 12 & 43 & \\
& Sangat & $(72,1 \%)$ & $(27,9 \%)$ & $(100,0 \%)$ & \\
& Berat & $(57,5 \%)$ & $(42,5 \%)$ & $(100,0 \%)$ & \\
\hline & Total & 102 & 84 & 186 & \\
& $(54,8 \%)$ & $(45,2 \%)$ & $(100,0 \%)$ & \\
\hline
\end{tabular}

Berdasarkan tabel 7 menunjukkan bahwa dari 20 orang responden dengan tingkat stres normal ditemukan 5 orang $(25,0 \%)$ yang mengalami gastritis, dari 16 orang responden dengan tingkat ringan ditemukan 5 orang $(31,3 \%)$ mengalami gastritis. Selanjutnya, dari 27 orang responden dengan tingkat stres sedang terdapat 15 orang $(55,6 \%)$ diantaranya mengalami gastritis. Responden dengan tingkat stres berat berjumlah 43 orang dan yang mengalami gastritis sebanyak 31 orang $(72,1 \%)$, responden dengan tingkat stres sangat berat berjumlah 80 orang dan 46 orang $(57,5 \%)$ diantaranya menderita gastritis.

\section{Discuss}

\section{Hubungan Pola Makan dengan Kejadian Gastritis}

Perilaku makan sehat adalah perilaku mengkonsumsi beberapa varian kelompok makanan yang dianjurkan, yaitu karbohidrat, buah dan sayur yang berlaku umum, protein dan lemak. Buah dan sayur merupakan sumber makanan yang mengandung vitamin dan mineral yang menunjang fungsi fisiologis tubuh (Fatimah, 2020a). Pada umumnya vitamin dan mineral hanya dibutuhkan dalam jumlah sedikit, namun karena vitamin dan mineral tersebut tidak dapat dibentuk oleh tubuh, maka harus didukung dengan suplai makanan yang mengandung vitamin dan mineral secara teratur sesuai dengan kebutuhan tubuh (Manullang, 2015).

Setelah uji statistik yang dilakukan pada variabel pola makan dengan variabel gastritis diperoleh nilai $\mathrm{P}$ value adalah 0,565 yang berarti $\mathrm{P}>\alpha(0,05)$, sehingga dapat disimpulkan bahwa tidak ada hubungan antara pola makan dengan kejadian gastritis pada mahasiwa 
Fakultas Ilmu Kesehatan Univeristas Ibn Khaldun Bogor. Selain itu, dari hasil analisis juga diperoleh pula nilai $\mathrm{OR}=1,238$ yang berarti mahasiswa dengan pola makan buruk mempunyai peluang menderita gastritis 1,238 kali lebih besar dibandingkan dengan mahasiswa dengan pola makan baik. Penelitian ini tidak sejalan dengan penelitian yang dilakukan oleh Novitasary (2017) tentang "Faktor Determinan Gastritis Klinis Pada Mahasiswa Di Fakultas Kesehatan Masyarakat Universitas Halu Oleo Tahun 2016" yang menunjukkan ada hubungan antara pola makan dengan kejadian gastritis pada mahasiswa fakultas kesehatan masyarakat Universitas Halu Oleo.

Menurut Persagi (2007), gastritis biasanya terjadi karena adanya frekuensi makan yang tidak teratur sehingga menyebabkan lambung menjadi sensitive dan asam lambung mengalami peningkatan. Pola makan yang tidak teratur akan menyebabkan lambung sulit untuk beradaptasi, jika hal ini terjadi dalam jangka waktu yang lama akan terjadi kelebihan asam lambung yang mengakibatkan mukosa lambung menjadi iritasi dan timbullah gastritis (Sumbara, 2020).

Penelitian ini sejalan dengan penelitian yang dilakukan oleh Nirmalarumsari (2020) yang berjudul "Faktor Risiko Kejadian Gastritis di Wilayah Kerja Puskesmas Bantilang Tahun 2019" menunjukkan bahwa tidak ada hubungan yang bermakna antara pola makan terhadap kejadian gastritis. Gastritis bukan merupakan suatu penyakit tunggal, melaikan mengacu kepada peradangan lambung. Peradangan tersebut biasanya terjadi akibat dari infeksi bakteri yang dapat mengakibatkan borok lambung. Bakteri ini disebut dengan Helicobacter Pylory merupakan satu-satunya bakteri yang hidup di lambung (Shalahuddin, 2018).

Menurut Yatmi (2017) menyebutkan bahwa bahwa banyak faktor yang dapat menyebabkan terjadinya gastritis seperti beberapa jenis obat, infeksi bakteri/virus/jamur, konsumsi alkohol, stres akut, radiasi, alergi atau intoksikasi dari beberapa bahan makanan atau minuman, dll. Asam lambung dapat terkontrol meskipun penderita memiliki frekuensi makan/pola makan yang kurang dari 3 kali sehari apabila diselingi oleh konsumsi makanan ringan yang tidak membuat lambung iritasi (Pratiwi, 2013). Siswa harus memperhatikan kebiasaan makannya dan mengikuti "Pedoman Gizi Seimbang", seperti makan lebih banyak sayuran dan buah-buahan yang cukup, membiasakan makan lauk berprotein tinggi, minum cukup makanan dan air yang aman, dan melakukan aktivitas fisik yang cukup. dan menjaga berat badan normal (Adinda, 2021 ;Fatimah, 2020b).

Berdasarkan ulasan diatas, peneliti berasumsi bahwa pola makan bukan merupakan faktor tunggal yang dapat menyebabkan terjadinya gastritis, akan tetapi pola makan saling 
berhubungan dengan faktor penyebab kejaidan gastritis lain pada rentang waktu yang lama sehingga timbullah penyakit gastritis pada diri seseorang. Belum terlaksananya pola makan yang baik pada beberapa responden bisa dikaitkan dengan faktor sehari-hari yang dijalani oleh responden sehingga menyebabkan responden kurang memperhatikan pola makannya, disisi lain juga ada faktor budaya, agama, serta ekonomi dan status kesehatan yang nantinya dapat menurunkan nafsu makan responden (Saputra, 2011).

\section{Hubungan Stres dengan Kejadian Gastritis}

Berdasarkan hasil uji statistik yang dilakukan diperoleh nilai $\mathrm{P}$ value $=0,003$ yang berarti $\mathrm{P}<\alpha(0,05)$ sehingga bisa dikatakan bahwa terdapat hubungan yang bermakna antara stres dengan kejadian gastritis.

Hasil penelitian ini sejalan dengan penelilitian yang dilakukan oleh Ausrianti (2019) tentang "Hubungan Pola Makan dan Faktor Stres Dengan Kejadian Gastritis Di Poliklinik Penyakit Dalam RSUP Dr.M Jamil Padang Tahun 2018" yang menunjukkan ada hubungan antara faktor stres dengan kejadian gastritis. Selain itu, penelitian ini juga sepaham dengsaan penelitian yang dilakukan oleh Uwa (2019) dengan judul "Hubungan Antara Stres dan Pola Makan Dengan Kejadian Gastritis Yang Terjadi Di Puskesmas Dinoyo" yang menunjukkan hasil ada hubungan antara stres dengan kejadian gastritis yang terjadi di puskesmas Dinoyo.

Stres lebih banyak terjadi karena adanya ketidakmampuan seseorang untuk menghadapi beban pekerjaan diluar kapasitasnya. Tubuh akan mengalami perubahan psikologik saat merespons stres, perubahan ini akan mempengaruhi fungsi organ yang ada didalam tubuh, salah satunya yaitu organ pencernaan. Stres memicu perubahan hormonal dalam tubuh sehingga merangsang sel-sel pada lambung untuk memproduksi asam lambung secara berlebihan, jika hal ini berlangsung dalam waktu yang lama dapat menyebabkan terjadinya gastritis (Mappagerang, 2017).

Penelitian Osamor (2015) menunjukkan bahwa anggota keluarga juga menyediakan sup-port emosional yang membantu pasien mengatasi stres karena penyakit mereka. Ketika keluarga memberikan dukungan kepada pasien, kondisi pasien akan membaik. Peningkatan dukungan keluarga akan dikaitkan dengan kontrol tekanan darah yang lebih baik pada pasien hipertensi (Tarigan, 2021).

Stres mengakibatkan penurunan semua kinerja organ tubuh, organ tubuh kerjanya diatur oleh reseptor otak maka ketika reseptor otak mengalami kondisi stres akan mengakibatkan tubuh akan mudah lelah hal tersebut akan menganggu kinerja saah satunya 
pada sistem pencernaan yang tidak sempurna sehingga bisa menyebabkan gastritis (Uwa et al., 2019). Sistem persyarafan dari otak berhubungan langsung dengan lambung, saat seseorang stres tanpa disadari memicu produksi asam lambung yang berlebih. Asam lambung inilah yang menyebabkan rasa nyeri pada lambung sehingga timbul gastritis (Mustika, 2021).

Dari hal tersebut maka responden harus bisa mengendalikan stres sehingga mampu juga mengendalikan gastritis yang dialami. Untuk mengendalikan stres cara yang bisa dilakukan diantaranya dengan melakukan istirahat yang cukup, bersikap positif dan optimis, serta melakukan liburan atau bersantai bersama teman atau keluarga.

\section{Conclusions}

Berdasarkan hasil penelitian mengenai hubungan pola makan dan stres dengan kejadian gastritis pada mahasiswa Fakultas Ilmu Kesehatan Universitas Ibn Khaldun Bogor dapat disimpulkan bahwa tidak ada hubungan antara pola makan dengan kejadian gastritis dibuktikan dengan nilai $\mathrm{P}$ value $=0,565$ dan terdapat hubungan antara stres dengan kejadian gastritis dengan nilai $\mathrm{P}$ value $=0,003$.

Untuk penelitian selanjutnya perlu dilakukan pengujian kembali mengenai pola makan dengan kuesioner Food Recall 24,Dietary History, atau Food Frequency Questionnaire untuk membuktikan bahwa pola makan berhubungan dengan kejadian gastritis dan dapat menemukan faktor lain yang dapat menyebabkan kejadian gastritis.

\section{References}

Adinda, D. (2020). Gambaran Kebiasaan Makan, Body Image Dan Status Gizi Remaja Putri di SMK Negeri 2 Sibolga. Contagion: Scientific Periodical Journal Of Public Health And Coastal Health, 2(1), 39-50. https://doi.org/10.30829/contagion.v2i1.7787

Adinda, D. (2021). Body Image and Eating Habits of Students Female Student at Vokasi Senior High School Sibolga. International Archives of Medical Sciences and Public Health, 2(1), 24-32.

Anshari, S. N., \& Suprayitno, S. (2019). Hubungan Stres Dengan Kejadian Gastritis Pada Kelompok Usia 20-45 Tahun Di Wilayah Kerja Puskesmas Bengkuring Kota Samarinda Tahun 2019. Borneo Student Research, 140-145.

Ausrianti, R., \& Nurleni, N. (2019). Hubungan Pola Makan Dan Faktor Stress Dengan Kejadian Gastritis Di Polikinik Penyakit Dalam RSUP Dr. M Jamil Padang Tahun 2018. MENARA Ilmu, XIII(4), 105-112.

Dhaneswara, D. P. (2016). Faktor yang Mempengaruhi Niat Makan Sayur dan Buah Pada Mahasiswa Asrama Universitas Airlangga. Jurnal Promkes, 4(1), 34-47.

Diliyana, Y. F., \& Utami, Y. (2020). Hubungan Pola Makan dengan Kejadian Gastritis pada Remaja di Wilayah Kerja Puskesmas Balowerti Kota Kediri. Journal of Nursing Care \& 
Biomolecular, 5(1), 19-24.

Emryssyah, C. J. (2021). Characteristics, Demographics And Malnutisi Of Toddlers In West Papua Province. Contagion: Scientific Periodical of Public Health and Coastal Health, 3(1), 42-53. https://doi.org/10.30829/contagion.v3i1.9270

Fatimah, P. S. (2020a). Konsumsi Buah, Sayur Dan Ikan Berdasarkan Sosio Demografi Masyarakat Pesisir Provinsi Sumatera Utara. Uin Sumatera Utara. Contagion : Scientific Periodical of Public Health and Coastal Health, 2(1), 51-63. https://doi.org/10.30829/contagion.v2i1.7630

Fatimah, P. S. (2020b). Pola Konsumsi Buah dan Sayur Dengan Kejadian Diabetes Mellitus Pada Masyarakat Pesisir. Bali Health Published Journal, 2(1), 26-36.

Handayani, M., \& Thomy, T. A. (2018). Hubungan Frekuensi, Jenis Dan Porsi Makan Dengan Kejadian Gastritis Pada Remaja. Jurnal Kesehatan Saelmakers PERDANA, 1(2), 40-46. https://doi.org/10.32524/jksp.v1i2.379

Hartati, S., Utomo, W., \& Jumaini, J. (2014). Hubungan Pola Makan Dengan Resiko Gastritis Pada Mahasiswa Yang Menjalani Sistem KBK. Jurnal Online Mahasiswa Program Studi Ilmu Keperawatan, I(2).

Manullang, R. M. A. (2015). Hubungan Tingkat Pengetahuan dengan Pola Konsumsi Buah dan Sayur pada Mahasiswa Fakultas Kedokteran Universitas Sumatera Utara Angkatan 2014 di Medan Tahun 2015. Universitas Sumatera Utara.

Mappagerang, R., \& Hasnah, H. (2017). Kejadian Gastritis Diruang Rawat Inap RSUD Nene Mallomo Kabupaten Sidrap. Jurnal Ilmu Kesehatan Pencerah, 6, 59-64.

Merita, M., Sapitri, W. I., \& Sukandar, I. (2016). Hubungan Tingkat Stress Dan Pola Konsumsi Dengan Kejadian Gastritis Di Puskesmas Pakuan Baru Jambi. Jurnal Akademika Baiturrahim, 5(1), 51-58.

Mustika, A. M., Dasuki, D., \& Saswati, N. (2021). Gambaran Pola Makan dan Stress Pada Penderita Gastritis di Puskesmas Simpang IV Sipin Kota Jambi. Manuju: Malayahayati Nursing Journal, 3(2), 174-180.

Nirmalarumsari, C., \& Tandipasang, F. (2020). Faktor Risiko Kejadian Gastritis di Wilayah Kerja Puskesmas Bantilang Tahun 2019. Jurnal Ners Dan Kebidanan, 7(2), 196-202. https://doi.org/10.26699/jnk.v7i2.ART.p196

Notoatmodjo, S. (2014). Metodologi Penelitian Kesehatan. Jakarta: Rineka Cipta.

Novitasary, A., Sabilu, Y., \& Ismail, C. S. (2017). Faktor Determinan Gastritis Klinis Pada Mahasiswa Di Fakultas Kesehatan Masyarakat Universitas Halu Oleo Tahun 2016. Jurnal Ilmiah Mahasiswa Kesehatan Masyarakat, 2(6), 1-11.

Osamor. (2015). Social Support And Management Of Hypertension In South-West Nigeria. Cardiovasc J Afr, 26(1), 28-33.

Pratiwi, W. (2013). Hubungan Pola Makan Dengan Gastritis Pada Remaja Di Pondok Pesantren Daar El-Qolam Gintung, Jayanti, Tanggerang. Universitas Islam Negeri Syarif Hidayatullah Jakarta.

Putri, R. (2019). Hubungan Sosial Ekonomi dan Kebiasaan Makan Terhadap Kejadian Stunting pada Siswa SDN 11 Kampung Jua Kecamatan Lubuk Begalung Tahun 2019. Sekolah Tinggi Ilmu Kesehatan Perintis Padang.

Saputra, M. A. S., Tamzil, E., \& Murbiah, M. (2011). Hubungan Pola Makan dengan Kejadian Gastritis pada Pasien di Puskesmas Palembang. Jurnal Keperawatan STIKes Muhammadiyah Palembang, 1(1).

Shalahuddin, I., \& Rosidin, U. (2018). Hubungan Pola Makan Dengan Gastritis Pada Remaja Di Sekolah Menengah Kejuruan Ybkp3 Garut. Jurnal Kesehatan Bakti Tunas Husada: Jurnal Ilmu-Ilmu Keperawatan, Analis Kesehatan Dan Farmasi, 18(1), 33-44. https://doi.org/10.36465/jkbth.v18i1.303

Sumbara, S., \& Ismawati, Y. (2020). Hubungan Pola Makan dengan Kejadian Gastritis 
Wilayah Kerja Puskesmas Cinunuk. Jurnal Ilmiah Kesehatan Iqra, 8(1).

Susanti, N. (2020). Determinan Kejadian Hipertensi Masyarakat Pesisir Berdasarkan Kondisi

Sosio Demografi dan Konsumsi Makan. Jurnal Ilmiah Kesehatan (JIKA), 2(1), 43-52.

Syafi'i, M., \& Andriani, D. (2019). Faktor - faktor yang berhubungan dengan kejadian gastritis pada pasien yang berobat di puskesmas. Jurnal Keperawatan Dan Fisioterapi, 2(1), 52-60.

Tarigan, A. R. (2021). Analysis of Family Support and Diet Compliance in Hypertension Patients. Contagion : Scientific Periodical of Public Health and Coastal Health, 3(1), 16-28. https://doi.org/10.30829/contagion.v3i1.9123

Uwa, L. F., Milwati, S., \& Sulasmini, S. (2019). Hubungan Antara Stres dan Pola Makan dengan Kejadian Gastritis yang Terjadi di Puskesmas Dinoyo. Nursing News, 4(1), 237 247.

Wahyuni, P. E. S. (2018). Asuhan Keperawatan Keluarga Gastritis Dengan Manajemen Kesehatan Keluarga Tidak Efektif Di UPT Kesmas Sukawati 1 Gianyar Tahun 2018. Politeknik Kesehatan Kemenkes Denpasar.

Yatmi, F. (2017). Pola Makan Mahasiswa dengan Gastritis yang Terlibat dalam Organisasi Kemahasiswaan di Universitas Islam Negeri Jakarta. UIN Syarif Hidayatullah Jakarta.

Zainurridha, Y. A. (2021). Stres dan Pola Makan terhadap Kejadian Gastritis pada Mahasiswa Keperawatan Stikes Bhakti Al-Qodiri. Jurnal Keperawatan Dan Kebidanan, 6(1). 